\title{
Gambaran Kadar Trombosit, Besar Limpa dan Kadar Albumin Serum pada Pasien Sirosis Hati dengan Varises Esofagus
}

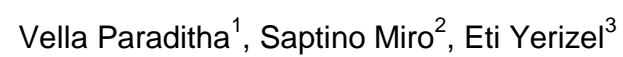

\section{Abstrak}

Varises esofagus merupakan komplikasi sirosis hati yang didiagnosis dengan endoskopi. Pada keadaan tertentu, pemeriksaan endoskopi tidak dapat dilaksanakan, sehingga diperlukan cara lain sebagai alternatif untuk menilai varises esofagus. Tujuan penelitian ini adalah mengetahui gambaran kadar trombosit, besar limpa dan kadar albumin serum pasien sirosis hati pada berbagai derajat varises esofagus. Penelitian ini berupa deskriptif retrospektif dengan instrumen data rekam medik pasien sirosis hati dengan varises esofagus yang telah menjalani pemeriksaan fisik, laboratorium dan endoskopi di RSUP dr. M. Djamil Padang dari Januari 2010 sampai Juli 2012. Sampel yang didapatkan berjumlah 33 pasien. Sebagian besar pasien mengalami trombositopenia. Penurunan kadar trombosit tidak berhubungan dengan peningkatan derajat varises esofagus. Besar limpa pada sebagian besar pasien dengan varises esofagus derajat 1, 2, maupun 3 adalah $\leq S 1$. Seluruh pasien mengalami hipoalbuminemia. Penurunan kadar albumin serum tidak berhubungan dengan peningkatan derajat varises esofagus. Penelitian ini menunjukkan bahwa penurunan kadar trombosit dan kadar albumin serum tidak berhubungan dengan peningkatan derajat varises esofagus. Tidak terdapat perbedaan besar limpa yang signifikan antara pasien dengan varises esofagus derajat 1, 2, maupun 3 . Direkomendasikan agar menggunakan jumlah sampel yang lebih banyak pada penelitian selanjutnya dan data yang digunakan sebaiknya diperoleh dari pemeriksa yang sama.

Kata kunci: kadar trombosit, besar limpa, kadar albumin, derajat varises esofagus

\begin{abstract}
Esophageal varices is a complication in liver cirrhosis which can be diagnosed by endoscopy. However, on certain conditions, endoscopy examination can not be performed. Another method is needed as an alternative to assess the esophageal varices. The objective of this study was to recognize platelet count, spleen size and serum albumin level of liver cirrhosis patient in each esophageal varices degree. This is a retrospective descriptive study. The instruments used in this study are the medical record data of liver cirrhosis patients that have esophageal varices, who have undergone physical, laboratory and endoscopy examinations in dr. M. Djamil Hospital Padang on January $2010-$ July 2012. Thirty-three patients were eligible for this study. The most of patients had thrombocytopenia. The decrease in platelet count was not related to the increase in esophageal varices degree. Spleen size in most of patients with first, second, and third degree esophageal varices was $\leq$ S1. All of patients had hypoalbuminemia. The decrease in albumin level was not related to the increase in esophageal varices degree. This study showed that the decrease in platelet count and albumin level were not related to the increase in esophageal varices degree. There was no significant difference in spleen size between patients with first, second, or third degree esophageal varices.
\end{abstract}

Keywords: platelet count, spleen size, albumin level, esophageal varices degree

Affiliasi penulis: 1. Prodi Profesi Dokter FK UNAND (Fakultas Kedokteran Universitas Andalas Padang), 2. Bagian IImu Penyakit Dalam FK UNAND, 3. Bagian Biokimia FK UNAND.
Korespondensi: Vella Paraditha, e-mail :

vellaparaditha12@gmail.com. Telp : 082382131432. 


\section{PENDAHULUAN}

Sirosis hati merupakan stadium akhir dari penyakit hati kronis yang menggambarkan fibrosis hepatik yang berlangsung progresif dan pembentukan nodulus regeneratif. ${ }^{1,2}$ Berbagai komplikasi dapat timbul pada sirosis hati akibat kegagalan fungsi hati maupun akibat hipertensi portal. Komplikasi tersebut diantaranya adalah edema dan asites, peritonitis bakterial spontan, perdarahan saluran cerna, ensefalopati hepatik, sindroma hepatorenal, sindroma hepatopulmonar, hipersplenisme dan kanker hati. ${ }^{3}$ Penyebab perdarahan saluran cerna yang paling sering pada sirosis adalah perdarahan dari varises esofagus. Di Indonesia, kebanyakan perdarahan saluran cerna bagian atas disebabkan oleh ruptur varises esofagus, sedangkan di negara barat, penyebab utama perdarahan tersebut adalah perdarahan ulkus peptikum dan gastritis erosiva. ${ }^{4}$ Varises esofagus merupakan pelebaran pembuluh darah vena esofagus yang menonjol ke lumen esofagus. Varises tersebut terbentuk akibat hipertensi portal yang terjadi pada sirosis hati. ${ }^{5}$ Varises esofagus dapat didiagnosis dengan menggunakan endoskopi, yang merupakan gold standard. ${ }^{6}$ Berdasarkan pemeriksaan endoskopi tersebut, varises esofagus dapat diklasifikasikan atas beberapa derajat. ${ }^{7}$ Akan tetapi, tidak semua pusat kesehatan yang memiliki endoskopi sehingga diperlukan cara lain sebagai alternatif untuk meramalkan serta menilai varises esofagus. Pada keadaan tertentu, pemeriksaan endoskopi tidak bisa dilaksanakan, seperti kondisi kesehatan pasien yang tidak memungkinkan dan menjadi kontraindikasi untuk pelaksanaan endoskopi, maupun jika pasien tidak bersedia. Menurut beberapa penelitian, terdapat beberapa prediktor non-endoskopi yang dapat digunakan untuk menilai varises esofagus, di antaranya adalah jumlah trombosit dan besar limpa. Pada tahun 2011, Cherian et al menyimpulkan bahwa jumlah trombosit yang rendah, Child-Pugh B dan C, serta diameter limpa dapat digunakan sebagai prediktor untuk diagnosis varises esofagus. ${ }^{8}$ Pada tahun 2010, Sarangapani et al juga melakukan penelitian untuk menilai varises esofagus yang berukuran besar melalui beberapa parameter noninvasif. Penelitian tersebut memberikan hasil bahwa trombositopenia, ukuran limpa yang besar, ukuran vena portal dan rasio trombosit dengan diameter limpa merupakan prediktor kuat keberadaan varises esofagus. ${ }^{9}$ Pada tahun 2007, Miro juga memperoleh hasil penelitian bahwa jumlah trombosit, diameter vena portal, besar limpa dan Klasifikasi Child-Pugh memiliki korelasi dengan derajat varises esofagus. ${ }^{5}$

Pada tahun 2011, Budiyasa et al melakukan penelitian untuk mengetahui hubungan kadar albumin serum dengan derajat varises esofagus. Penelitian tersebut menghasilkan kesimpulan bahwa terdapat hubungan antara derajat varises esofagus dengan kadar albumin serum. Kadar albumin serum juga dapat digunakan sebagai prediktor derajat varises esofagus. ${ }^{10}$ Penelitian ini bertujuan untuk mengetahui gambaran kadar trombosit, besar limpa dan kadar albumin serum pada pasien sirosis hati dengan varises esofagus.

\section{METODE}

Penelitian dilakukan di Instalasi Rekam Medik RSUP dr. M. Djamil Padang. Pengambilan data dilakukan pada Desember 2012 sampai Januari 2013. Sampel penelitian adalah 33 pasien yang secara klinis telah didiagnosis sebagai penderita sirosis hati dan telah menjalani pemeriksaan laboratorium, serta didiagnosis memiliki varises esofagus pada pemeriksaan endoskopi, yang tercatat di rekam medik RSUP. dr. M. Djamil Padang selama tahun 2010-2012. Kriteria eksklusi adalah data yang diperoleh tidak lengkap, penderita sirosis hati dengan penyakit lain yang memengaruhi jumlah trombosit, seperti keganasan, infeksi dan lain-lain; penderita sirosis hati dengan penyakit lain yang memengaruhi besar limpa, seperti malaria; serta penderita sirosis hati dengan penyakit lain yang memengaruhi kadar albumin. Instrumen penelitian adalah rekam medik pasien.

Data rekam medik pasien sirosis hati yang telah menjalani pemeriksaan endoskopi dan pemeriksaan laboratorium pada tahun 2010-2012 dinilai satu persatu untuk memeriksa kejelasan dan kelengkapannya. Gambaran endoskopi pasien dikelompokkan berdasarkan derajat varises esofagus, yaitu derajat I, II dan III. Data besar limpa pasien dikelompokkan menjadi $\leq \mathrm{S} 1$, S2 dan $\geq \mathrm{S} 3$. Seluruh 
data yang telah diperoleh dimasukkan ke dalam program komputer. Analisis data yang digunakan adalah analisis univariat dan analisis bivariat. Analisis bivariat yang digunakan adalah chi-square untuk variabel limpa dan ANOVA untuk variabel kadar trombosit dan kadar albumin serum.

\section{HASIL}

\section{Derajat Varises Esofagus}

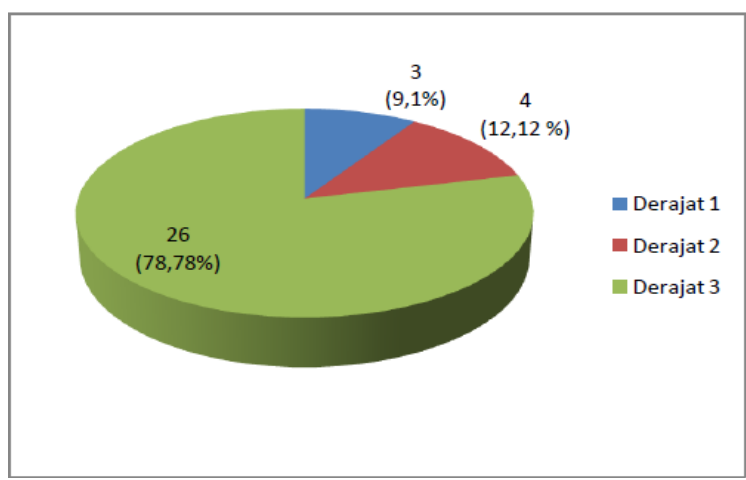

Gambar 1. Distribusi frekuensi subjek penelitian berdasarkan derajat varises esofagus pada pasien sirosis hati

Berdasarkan Gambar 1, dapat dilihat bahwa distribusi frekuensi subjek penelitian berdasarkan derajat varises esofagus pada pasien sirosis hati adalah 3 orang dengan varises esofagus derajat 1 $(9,1 \%), 4$ orang dengan varises esofagus derajat 2 $(12,12 \%)$ dan 26 orang dengan varises esofagus derajat $3(78,78 \%)$.

\section{Gambaran Kadar Trombosit Pasien Sirosis Hati pada Berbagai Derajat Varises Esofagus}

Tabel 1. Gambaran rerata kadar trombosit pasien sirosis hati pada berbagai derajat varises esofagus

\begin{tabular}{|c|c|c|c|c|c|}
\hline \multirow{2}{*}{$\begin{array}{l}\text { Derajat } \\
\text { Varises }\end{array}$} & \multirow[b]{2}{*}{$\mathrm{n}$} & \multicolumn{3}{|c|}{ Kadar Trombosit } & \multirow{3}{*}{$\mathrm{p}$} \\
\hline & & Mean & Min & Max & \\
\hline Esofagus & & $\pm S D$ & & & \\
\hline \multirow[t]{2}{*}{1} & 3 & 50.000 & 17.000 & 92.000 & \multirow{6}{*}{0,173} \\
\hline & & \pm 38.301 & & & \\
\hline \multirow[t]{2}{*}{2} & 4 & 69.000 & 39.000 & 134.000 & \\
\hline & & \pm 43.779 & & & \\
\hline \multirow[t]{2}{*}{3} & 26 & 134.346 & 22.000 & 373.000 & \\
\hline & & \pm 97.178 & & & \\
\hline Total & 33 & & & & \\
\hline
\end{tabular}

Pada Tabel 1 diperoleh hasil bahwa nilai rerata kadar trombosit pada pasien sirosis hati dengan varises esofagus derajat 1 adalah $50.000 / \mathrm{mm} 3$ (SD 38.301), pada derajat 2 adalah 69.000/mm3 (SD 43.779), dan pada derajat 3 adalah 134.346/mm3 (SD 97.178). Terlihat bahwa sebagian besar pasien mengalami trombositopenia. Pasien dengan varises esofagus derajat 3 masih bisa memiliki kadar trombosit normal. Uji ANOVA yang telah dilakukan, diperoleh $p=0,173$ ( $p>0,05)$ yang artinya tidak terdapat perbedaan rerata kadar trombosit pada pasien sirosis hati dengan varises esofagus derajat 1 , 2, maupun 3. Berarti tidak terdapat hubungan antara kadar trombosit dengan derajat varises esofagus

\section{Gambaran Besar Limpa Pasien Sirosis Hati pada Berbagai Derajat Varises Esofagus}

Tabel 2. Gambaran besar limpa pasien sirosis hati pada berbagai derajat varises esofagus

\begin{tabular}{ccccc}
\hline Derajat & \multicolumn{3}{c}{ Besar Limpa } & \multirow{2}{*}{ Total } \\
\cline { 2 - 3 } Varises & $\leq \mathrm{S} 1$ & $\mathrm{~S} 2$ & $\geq \mathrm{S} 3$ & \\
\cline { 2 - 4 } Esofagus & $\mathrm{n}(\%)$ & $\mathrm{n}(\%)$ & $\mathrm{n}(\%)$ & $3(100)$ \\
\hline 1 & $3(100)$ & $0(0)$ & $0(0)$ & $4(100)$ \\
2 & $2(50)$ & $2(50)$ & $0(0)$ & $4(100)$ \\
3 & $17(65,4)$ & $7(26,9)$ & $2(7,7)$ & $26(100)$ \\
\hline Total (\%) & $22(66,7)$ & $9(27,3)$ & $2(6,1)$ & $33(100)$ \\
\hline
\end{tabular}

Tabel 2 memperlihatkan beberapa sel yang bernilai 0 sehingga tabel tersebut tidak layak untuk diuji dengan chi square. Berdasarkan tabel tersebut, didapatkan hasil bahwa besar limpa pada pasien dengan varises esofagus derajat 1 adalah $\leq \mathrm{S} 13$ orang (100\%), dan tidak ada yang memiliki limpa berukuran S2 $(0 \%)$, maupun $\geq$ S3 $(0 \%)$. Besar limpa pada pasien dengan varises esofagus derajat 2 adalah $\leq$ S1 2 orang $(50 \%)$, S2 2 orang $(50 \%)$, dan tidak ada yang memiliki limpa berukuran $\geq$ S3 (0\%). Pada pasien dengan varises esofagus derajat 3 , besar limpa yang didapatkan adalah $\leq$ S1 17 orang $(65,4 \%)$, S2 7 orang $(26,9 \%)$, dan $\geq$ S3 2 orang $(7,7 \%)$. 


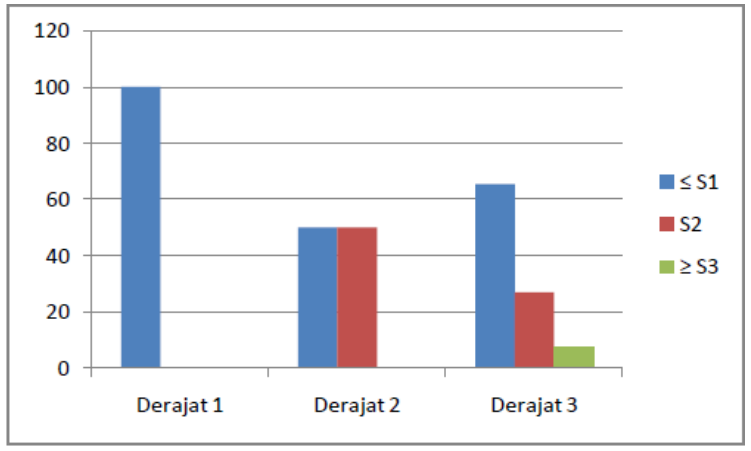

Gambar 2. Distribusi frekuensi besar limpa berdasarkan derajat varises esofagus pada pasien sirosis hati

Berdasarkan Gambar 2, dapat dilihat bahwa besar limpa $\leq \mathrm{S} 1$ dapat ditemukan pada pasien dengan varises esofagus derajat 1, 2, maupun 3 . Besar limpa S2 ditemukan pada pasien dengan varises esofagus derajat 2 dan 3, sedangkan besar limpa $\geq$ S3 hanya ditemukan pada pasien dengan varises esofagus derajat 3

\section{Gambaran Kadar Albumin Serum Pasien Sirosis} Hati pada Berbagai Derajat Varises Esofagus

Tabel 3. Gambaran kadar albumin serum pasien sirosis hati pada berbagai derajat varises esofagus

\begin{tabular}{cccccc}
\hline Derajat & & \multicolumn{3}{c}{ Kadar Albumin Serum $(\mathrm{g} / \mathrm{dL})$} & \\
\cline { 3 - 4 } Varises & $\mathrm{n}$ & Mean \pm SD & Min & Max & $\mathrm{p}$ \\
Esofagus & & & & & \\
\hline 1 & 3 & $2,20 \pm 0,84$ & 1,4 & 3,1 & \\
2 & 4 & $2,52 \pm 0,49$ & 1,9 & 3,1 & 0,622 \\
3 & 26 & $2,58 \pm 0,64$ & 1,5 & 3,4 & \\
\hline Total & 33 & & & & \\
\hline
\end{tabular}

Berdasarkan Tabel 3, dapat dilihat bahwa nilai rerata kadar albumin serum pada pasien sirosis hati dengan varises esofagus derajat 1 adalah 2,20 g/dL (SD 0,84), pada derajat 2 adalah 2,52 g/dL (SD 0,49), dan pada derajat 3 adalah 2,58 g/dL (SD 0,64). Terlihat bahwa seluruh pasien mengalami hipoalbuminemia. Berdasarkan uji ANOVA yang telah dilakukan, diperoleh nilai $p=0,622(p>0,05)$ yang artinya tidak terdapat perbedaan rerata kadar albumin serum pada pasien sirosis hati dengan varises esofagus derajat 1, 2, maupun 3. Berarti, tidak terdapat hubungan antara kadar albumin serum dengan derajat varises esofagus.

\section{PEMBAHASAN}

Pada penelitian ini, dapat terlihat bahwa banyak pasien sirosis hati yang datang ke RS setelah penyakitnya sudah lanjut dan varises esofagusnya sudah berukuran besar.

Berdasarkan hasil yang ditemukan, dapat dilihat bahwa semakin tinggi derajat varises esofagus, maka kadar trombosit juga semakin tinggi. Peneliti mendapati beberapa pasien dengan varises esofagus derajat 3 masih memiliki kadar trombosit lebih dari 150.000/mm3. Hasil penelitian ini serupa dengan hasil yang diperoleh Qamar dan Grace pada tahun 2009. Berdasarkan penelitian prospektif tersebut, didapatkan $14 \%$ pasien dengan varises esofagus berukuran besar ataupun telah mengalami perdarahan memiliki kadar trombosit yang normal. ${ }^{11}$

Pada pasien sirosis hati dapat ditemukan trombositopenia. Hal itu terjadi karena adanya peningkatan sekuestrasi trombosit di dalam limpa akibat spenomegali, maupun karena menurunnya produksi trombopoeitin di hati. ${ }^{9,11}$ Hipertensi porta yang terjadi pada sirosis hati menimbulkan splenomegali kongestif sehingga sekuestrasi trombosit di dalam limpa meningkat sebanyak 50\% hingga 90\%. ${ }^{12}$ Peningkatan destruksi trombosit pada limpa yang diperantarai oleh $\operatorname{lgG}^{9}$ Menurut penelitian Adinolfi et al tahun 2001, prevalensi trombositopenia lebih tinggi pada derajat fibrosis hati yang telah lanjut. Meskipun telah terjadi splenomegali, kadar trombosit masih bisa normal pada derajat fibrosis hati yang masih awal dan kadar trombopoietin yang masih normal. Pada fibrosis hati lanjut, yaitu derajat 3 dan 4, produksi trombopoietin tidak adekuat sehingga menyebabkan penurunan kadar trombosit. ${ }^{13}$ Mekanisme lain yang juga berpengaruh dalam penurunan kadar trombosit adalah inhibisi pada sumsum tulang dan mekanisme autoimun. ${ }^{14}$

Pada hipertensi portal dapat terjadi keadaan hipersplenismus, yaitu suatu sindrom klinik yang terdiri dari splenomegali dan sitopenia (anemia, leukopenia, trombositopenia). Meskipun splenomegali selalu ditemukan pada hipersplenismus, banyak pasien dengan splenomegali yang tidak mengalami hipersplenismus. ${ }^{15}$ Oleh karena itu, tidak adanya trombositopenia pada beberapa sampel penelitian ini 
kemungkinan disebabkan karena tidak terjadinya keadaan hipersplenismus pada pasien tersebut.

Pada penelitian ini, diperoleh $p=0,173(p>$ $0,05)$ setelah dilakukan uji statistik ANOVA, yang berarti bahwa tidak terdapat perbedaan rerata kadar trombosit pada pasien dengan varises esofagus derajat 1, 2, maupun 3. Berdasarkan hasil penelitian ini, tidak diperoleh hasil yang menyatakan bahwa terdapat hubungan antara kadar trombosit dengan derajat varises esofagus. Hasil ini berbeda dengan beberapa penelitian lain. Berbagai penelitian telah dilakukan sehingga diperoleh kesimpulan bahwa terdapat hubungan antara kadar trombosit dengan derajat varises esofagus. Semakin tinggi derajat varises esofagus, maka kadar trombosit semakin rendah. Miro dalam penelitiannya pada tahun 2007, memperoleh hasil bahwa terdapat adanya korelasi kuat yang berpola negatif antara jumlah trombosit dengan derajat varises esofagus, dengan $r=-0,74$ pada analisis multivariat. Pada beberapa penelitian juga didapatkan kadar trombosit tertentu sebagai prediktor kemunculan varises esofagus. ${ }^{5}$ Menurut Cherian et al, kadar trombosit $<90,000$ per $\mu$ l dapat digunakan sebagai prediktor varises esofagus berukuran besar. ${ }^{8}$

Kelemahan penelitian ini adalah jumlah sampel yang sedikit sehingga tidak diperoleh adanya hubungan antara variabel. Selain itu, terdapat perbedaan jumlah sampel yang cukup jauh antara varises esofagus derajat 1,2 , dan 3 . Jumlah data yang sedikit juga tidak memungkinkan untuk dilakukannya seleksi sampel dengan kriteria yang lebih ketat sehingga kemungkinan masih terdapat penyebab lain yang dapat memengaruhi kadar trombosit.

Pada penelitian ini, dapat dilihat bahwa tidak ada perbedaan besar limpa yang signifikan antara pasien sirosis hati dengan derajat 1,2, maupun 3 karena pada umumnya pasien tersebut memiliki besar limpa $\leq$ S1. Hasil penelitian ini tidak memenuhi syarat untuk dianalisis dengan uji chi-square karena terdapatnya sel dengan nilai 0 . Namun, dengan membandingkan hasil besar limpa yang diperoleh pada setiap derajat varises esofagus, dapat dilihat bahwa hasil penelitian ini tidak sesuai dengan penelitian sebelumnya bahwa semakin besar derajat varises esofagus, maka ukuran limpa juga semakin besar. Hal ini terlihat pada pasien dengan varises esofagus derajat 3 yang kebanyakan masih memiliki besar limpa $\leq$ S1, yaitu 17 orang dari 26 sampel. Pada sirosis hati terjadi peningkatan tekanan di sistem portal. Hal ini menimbulkan peningkatan blokade aliran darah dari limpa sehingga limpa dapat membesar secara progresif dan terjadilah splenomegali. ${ }^{3}$ Jadi, hipertensi portal tidak hanya mengakibatkan terbentuknya varises esofagus, tetapi juga pembesaran limpa (splenomegali).

Berbagai penelitian memperoleh hasil, bahwa pada sirosis hati terdapat hubungan antara besar limpa dengan derajat varises esofagus. Pada tahun 2011, Cherian et al meneliti hubungan antara diameter bipolar limpa yang diukur dengan USG, dengan derajat varises esofagus. Penelitian tersebut menghasilkan $p=0,001(p<0,05) .{ }^{8}$ Hong et al pada tahun 2009 meneliti hubungan antara besar limpa, yang dinilai dari lebar limpa dengan dengan keberadaan varises esofagus pada pasien sirosis hati akibat infeksi Hepatitis B. Lebar limpa juga diukur dengan menggunakan USG. Dari penelitian tersebut, diperoleh $\mathrm{p}<0,001$ yang artinya terdapat hubungan antara lebar limpa dengan varises esofagus. ${ }^{16}$ Miro meneliti hubungan antara besar limpa, baik yang diukur dengan menggunakan USG maupun secara palpasi, dengan derajat varises esofagus. Penelitian tersebut juga menghasilkan hubungan antara besar limpa dengan derajat varises esofagus. ${ }^{5}$

Perbedaan hasil yang didapatkan ini, kemungkinan disebabkan karena jumlah sampel yang sedikit. Selain itu, pengukuran besar limpa dengan pemeriksaan fisik tidak dapat dipercaya karena pembesaran minor sering tidak terdeteksi secara palpasi. ${ }^{17}$ Hasil pengukuran limpa yang didapatkan merupakan hasil pemeriksaan yang dilakukan oleh beberapa orang sehingga subjektivitasnya tinggi. Oleh karena itu, metode palpasi mungkin tidak terlalu mewakili ukuran limpa yang sebenarnya bila dibandingkan dengan pemeriksaan lain, seperti pemeriksaan USG, yang diterapkan pada penelitianpenelitian sebelumnya.

Hasil penelitian ini menemukan kadar albumin pada pasien sirosis hati dengan varises esofagus, 
dapat dilihat bahwa terjadi hipoalbuminemia pada setiap derajat varises esofagus, tetapi kadar albumin serum semakin tinggi pada varises esofagus dengan derajat yang lebih tinggi.

Pada sirosis hati dapat terjadi hipoalbuminemia akibat gangguan sintesis albumin. Selain itu, hipoalbuminemia juga terjadi karena peningkatan pembersihan oleh sistem retikuloendotelial, peningkatan kehilangan albumin melalui sistem gastrointestinal, maupun akibat perubahan distribusi albumin yang lebih banyak ke kavum peritoneum. ${ }^{10,18}$

Pada penelitian ini diperoleh dari uji ANOVA adalah $p=0,622$, artinya tidak terdapat perbedaan rerata kadar albumin serum pada pasien dengan varises esofagus derajat 1,2 , maupun 3 . Hal ini menunjukkan bahwa tidak terdapat hubungan antara kadar albumin serum dengan derajat varises esofagus. Kesimpulan yang serupa juga didapatkan oleh Demirel et al melalui penelitiannya pada tahun 2003 mengenai hubungan kadar albumin serum dan kadar albumin cairan asites dengan derajat varises esofagus. Pada penelitian tersebut, diperoleh hasil bahwa tidak terdapat hubungan antara derajat varises esofagus dengan kadar albumin serum $(p=0,7) .{ }^{19}$

Hasil penelitian ini berbeda dengan penelitian oleh Budiyasa et al yang mendapatkan hasil bahwa terdapat korelasi negatif antara albumin serum dan derajat varises esofagus ( $p=0,000)$ yang artinya, semakin tinggi derajat varises esofagus, maka kadar albumin serum semakin rendah. ${ }^{10}$

Kelemahan penelitian ini adalah jumlah sampel yang sedikit dan perbedaan jumlah sampel yang jauh antara pasien dengan varises esofagus derajat 1, 2 dan 3. Selain itu, kriteria seleksi sampel hanya berdasarkan data yang terdapat pada rekam medik sehingga kemungkinan masih terdapat faktor lain yang memengaruhi kadar albumin, yang tidak tertulis $\mathrm{di}$ rekam medik.

\section{KESIMPULAN}

Derajat varises esofagus yang terbanyak adalah derajat 3 , yaitu varises esofagus yang menempati > 1/3 lumen esofagus.

Terdapat trombositopenia pada sebagian besar pasien sirosis hati dengan varises esofagus.
Penurunan kadar trombosit tidak berhubungan dengan peningkatan derajat varises esofagus.

Besar limpa $\leq \mathrm{S} 1$ ditemukan pada pasien dengan varises esofagus derajat 1, 2, maupun 3 . Besar limpa S2 ditemukan pada pasien dengan varises esofagus derajat 2 dan 3, sedangkan besar limpa $\geq$ S3 hanya ditemukan pada pasien dengan varises esofagus derajat 3 .

Terdapat hipoalbuminemia pada seluruh pasien sirosis hati dengan varises esofagus derajat 1,2 , maupun 3.

Penurunan kadar albumin serum tidak berhubungan dengan peningkatan derajat varises esofagus.

\section{UCAPAN TERIMA KASIH}

Terima kasih kepada semua pihak yang telah membimbing dan membantu penulis dalam menyelesaikan penelitian ini. Penulis juga mengucapkan terima kasih kepada pihak Instalasi Rekam Medik RSUP dr. M. Djamil Padang yang telah membantu penulis dalam rangka melaksanakan penelitian ini.

\section{DAFTAR PUSTAKA}

1. Hadi S. Gastroenterologi. Edisi ke-7. Bandung: Alumni; 2002.

2. Nurdjanah S. Sirosis hati. Dalam: Sudoyo AW, Setiyohadi B, Alwi I, Simadibrata M, Setiati S, editor (penyunting). Buku ajar ilmu penyakit dalam. Edisi ke-5. Jilid 1. Jakarta: Interna Publishing; 2009.

3. Kusumobroto HO. Sirosis hati. Dalam: Sulaiman A, Akbar MN, Lesmana LA, Noer HMS editor. Buku ajar ilmu penyakit hati. Edisi ke-1. Jakarta: Jayabadi; 2007.

4. Mulyadi Y. Endoscopic feature of upper gastrointestinal bleeding patient in Soedarso General Hospital Pontianak. The Indonesian Journal of Gastroenterology, Hepatology, and Digestive Endoscopy. 2010;11(3) :132-4.

5. Miro S. Hubungan antara parameter non-invasif dengan derajat varises esofagus pada sirosis hati (tesis). Padang: Bagian IImu Penyakit Dalam FK Universitas Andalas; 2007. 
6. Garcia-Tsao G, Sanyal AJ, Grace ND, Carey WD. Prevention and management of gastroesophageal varices and variceal hemorrhage in cirrhosis. Hepatology. 2007;46(3):922-38.

7. Waspodo AS. Hipertensi portal. Dalam : Sulaiman A, Akbar MN, Lesmana LA, Noer HMS, editor (penyunting). Buku ajar ilmu penyakit hati. Edisi ke1. Jakarta: Jayabadi; 2007.

8. Cherian JV, Deepak N, Ponnusamy RP, Somasundaram A, Jayanthi V. Non-invasive predictors of esophageal varices. Saudi J Gastroenterol. 2011; 7(1):64-8.

9. Sarangapani A, Shanmugam C, Kalyanasundaram M, Rangachari B, Thangavelu P, Subbarayan JK. Noninvasive prediction of large esophageal varices in chronic liver disease patients. Saudi J Gastroenterol. 2010;16(1):38-42.

10. Budiyasa DGA, Ariawan Y, Mariadi IK, Wibawa IDN, Purwadi N, Suryadarma IGA. Correlation between serum albumin level and degree of esophageal varices in patients with liver cirrhosis. The Indonesian Journal of Gastroenterology, Hepatology, and Digestive Endoscopy. 2011;12(1): 23-7.

11. Qamar AA, Grace ND. Abnormal hematological indices in cirrhosis. Can J Gastroenterol. 2009; 23(6):441-5.

12. Aster RH. Pooling of platelets in the spleen : role in the pathogenesis of "hypersplenic" thrombocytopenia. Journal of Clinical Investigation. 1966;45(5):645-57.

13. Adinolfi LE, Giordano MG, Andreana A, Tripodi MF, Utili R, Cesaro G. Hepatic fibrosis plays a central role in the pathogenesis of thrombocytopenia in patients with chronic viral hepatitis. British Journal of Haematology. 2001; 113(3):590-5.

14. Olariu M, Olariu C, Olteanu D. Thrombocytopenia in chronic hepatitis C. J Gastrointestin Liver Dis. 2010;19(4):381-5.

15. Hoffman R, et al. Hematology: Basic Principles and Practice. Philadelphia: Churchill Livingstone Elsevier; 2009.

16. Hong W, Zhu Q, Huang Z, Chen X, Jiang Z, Xu S. Predictors of esophageal varices in patients with HBV-related cirrhosis: a retrospective study. BMC Gastroenterology. 2009;9:11.

17. Moss PAH. The spleen. Dalam: Hoffbrand AV, et al, editor (penyunting). Postgraduate haematology. Edisi ke-6. Oxford: Blackwell Publishing Ltd; 2011.

18. Tietz NW. Textbook of clinical chemistry. Jilid 1. Philadelphia: WB Saunders Company; 1986.

19. Demirel U, Karincaoglu M, Harputluoglu M, Ates M, Seckin Y, Yildirim B. Two findings of portal hypertension: evaluation of correlation between serum-ascites albumin gradient and esophageal varices in non-alcoholic cirrhosis. Turk J Gastroenterol. 2003;14(4):219-22. 